\title{
Proton Exchange Membrane Based on Sulfonated Poly (Aromatic Imide-Co-Aliphatic Imide) for Direct Methanol Fuel Cell
}

\author{
Phornpussadee Umsarika ${ }^{a}$, Sairung Changkhamchom ${ }^{a}$, Nophawan Parade ${ }^{a}$, Anuvat Sirivat ${ }^{*}$, Pitt $^{2}$
}

Supaphol $^{a}$, Pimpa Hormnirun ${ }^{b}$

\author{
${ }^{a}$ The Petroleum and Petrochemical College, Chulalongkorn University, Bangkok 10330, Thailand \\ ${ }^{b}$ Department of Chemistry, Kasetsart University, Bangkok 10900, Thailand
}

Received: January 27, 2017; Revised: September 11, 2017; Accepted: November 10, 2017

\begin{abstract}
A new sulfonated poly(aromatic imide-co-aliphatic imide) (SPI) for the use as a polymer electrolyte membrane was successfully synthesized from 4,4'-diaminodiphenylmethane (DDM), 4,4'-diaminodiphenylmethane-2,2'-disulfonic acid disodium salt (S-DDM), hexamethylenediamine, and 3,3',4,4'-benzophenonetetracarboxylic dianhydride in a one-step reaction. S-DDM was prepared by the direct sulfonation of DDM monomer. The degree of sulfonation of the sulfonated copolyimide was varied by using various molar concentrations of S-DDM. The sulfonated copolyimide with the highest degree of sulfonation possessed the proton conductivity of $0.0032{\mathrm{~S} . \mathrm{cm}^{-1}}^{-1}$ a wet state. The highest methanol permeability of the sulfonated copolyimide was $2.75 \times 10^{-8} \mathrm{~cm}^{2} . \mathrm{s}^{-1}$ which is $\sim 425$ times lower than that of the Nafion 117 . The highest membrane selectivity belonged to the membrane with $34 \%$ degree of sulfonation with the value of $1.65 \times 10^{6} \mathrm{~s} .{\mathrm{S} . \mathrm{cm}^{-3}}^{-}$which is three orders of magnitude higher than the commercial Nafion 117.
\end{abstract}

Keywords: sulfonated poly(aromatic imide-co-aliphatic imide), proton conductivity, direct methanol fuel cell, methanol permeability.

\section{Introduction}

Direct methanol fuel cell (DMFC) has received much attention due to their high power density, high energy conversion efficiency, low emissions, as well as low pollution levels ${ }^{1}$. The main applications for DMFC are energy sources of small vehicles such as a forklift, consumer goods such as laptops, mobile phones, and digital cameras. The essential part of DMFC is the polymer electrolyte membrane (PEM) which acts as an electrolyte for transferring protons from the anode to the cathode, and a separator that prevents the mixing of the reactant gases. At present, various sulfonated perfluropolymers such as Nafion, Flemion, and Aciplex have been perceived as the highest proton conductive membranes in their fully hydrated states because they exhibit high proton conductivities and excellent chemical and mechanical stabilities. However, these commercial membranes have several drawbacks including high cost, high methanol crossover, and loss of proton conductivity at temperatures above $80^{\circ} \mathrm{C}$, which limit their application in $\mathrm{DMFC}^{2}$. Alternatively, J. Lobato et al., (2006) ${ }^{3}$ used a perfluorsulphonic polymer to produce a less expensive membrane namely the Sterion membrane; the Sterion L-180 and the Nafion 117 possessed the ionic resistances of 0.122 Ohms and $0.182 \mathrm{Ohms}$, respectively.

Recently, various types of polymer electrolyte membranes have been developed-poly(styrene sulfonic acid), sulfonated poly(ether ether ketone), sulfonated polysulfone ${ }^{2}$. Among these proton exchange membrane candidates, the sulfonated polyimide

*e-mail: anuvat.s@chula.ac.th has gained much attention because it has high mechanical, thermal, and chemical stabilities ${ }^{4-30}$. In addition, the chemical structure of its polymer backbone can be varied in different ways depending on the monomer selected. A variety of monomers can bring about flexibility or rigidity to the main chain.

In this work, a new sulfonated poly(aromatic imide-coaliphatic imide) (SPI) with different degrees of sulfonation were synthesized from 4,4'-diaminodiphenylmethane (DDM), sulfonated 4,4'-diaminodiphenylmethane (S-DDM), hexamethylenediamine (HDA), and 3,3',4,4'-benzophenonetetracarboxylic dianhydride (DTDA). The structure design of this SPI membrane was to combine the hydrophilic part namely the sulfonic acid side group to increase proton conductivity, and the hydrophobic aromatic polymer backbone to increase strength and flexibility and to lower methanol permeability. Fourier transform infrared spectroscopy was used to determine the structure of the synthesized sulfonated copolyimides. The ion exchange capacity (IEC), thermal stability, water uptake, degree of sulfonation (DS), proton conductivity, and methanol permeability were measured and investigated and compared with the commercial Nafion membrane.

\section{Experimental}

\subsection{Materials}

3,3',4,4'-Benzophenonetetracarboxylic dianhydride (BTDA; Aldrich, 96\%), 4,4'-diaminodiphenylmethane 
(DDM; Aldrich, 97\%), and hexamethylenediamine (HDA; Aldrich, 98\%) were used as starting monomers. For the sulfonation process, fuming sulfuric acid (Merck, 65\%) and concentrated sulfuric acid (Univar, 98\%) were used as the solvents. Benzoic acid (Univar, 99.9\%) as a catalyst, and triethylamine (Fluka, 98\%) were used in the membrane synthesis. Hydrochloric acid ( $\mathrm{HCl}$; Univar, 37\%) was used to protonate the synthesized membrane. Sodium chloride (Lab-Scan, 99.0\%) and sodium hydroxide (Univar, pellet purity $97 \%$ ) were used to determine the degree of sulfonation (DS) and the ion exchange capacity (IEC). Methanol (MeOH; Lab-Scan, 99.9\%) and ethanol (EtOH; Lab-Scan, 99.9\%) were used in the methanol permeability measurement.

\subsection{Synthesis of 4,4'-diaminodiphenylmethane- 2,2'-disulfonic acid disodium salt (S-DDM)}

To a round bottom flask, 4,4'-diaminodiphenylmethane (10 g, $50 \mathrm{mmol}$ ) and $20 \mathrm{~mL}$ of $98 \%$ sulfuric acid at $0{ }^{\circ} \mathrm{C}$ were added. Then, the reaction mixture was stirred until the 4,4'-diaminodiphenylmethane was completely dissolved, after which fuming sulfuric acid $(5 \mathrm{ml})$ was added. The reaction mixture was continuously stirred at $0{ }^{\circ} \mathrm{C}$ for $2 \mathrm{~h}$, followed by stirring at $80{ }^{\circ} \mathrm{C}$ for $2 \mathrm{~h}$. After cooling to room temperature, the solution was carefully poured over crushed ice. A sodium hydroxide solution was added to salt out the monomer precipitate. The resulting monomer precipitate was filtered off, washed with deionized water, and dried in vacuum for at least $24 \mathrm{~h}$.

\subsection{Synthesis of Sulfonated Poly(aromatic imide- co-aliphatic imide)}

The synthesis of SPI was performed by a one-step reaction. The molar ratio of S-DDM: DDM: HDA was fixed at 1: 4: 5 . In a round bottom flask, 4,4'-diaminodiphenylmethane2,2'-disulfonic acid disodium salt (S-DDM) (0.1219 g, 0.34 $\mathrm{mmol})$, triethylamine, hexamethylenediamine (0.1955 g, 1.6 $\mathrm{mmol})$, and DDM (0.2654 g, $1.33 \mathrm{mmol})$ were dissolved in dimethyl sulfoxide $(15 \mathrm{ml})$. The solution mixture was mechanically stirred under nitrogen atmosphere at $70{ }^{\circ} \mathrm{C}$. Next, BTDA (3.3 g, $10.0 \mathrm{mmol}$ ) was then added to the reaction mixture and benzoic acid $(0.1610 \mathrm{~g}, 1.32 \mathrm{mmol})$ was used as a catalyst for the polymerization process. The reaction was continuously stirred at ambient temperature for $24 \mathrm{~h}$ to obtain the synthesized polymer.

\subsection{Membrane Formation and Protonation}

The sulfonated poly(aromatic imide-co-aliphatic imide) film was prepared by a solution casting method. Polymer solution in DMSO was cast onto glass plate and dried in a vacuum oven at $80^{\circ} \mathrm{C}$ for $24 \mathrm{~h}$, followed by $100{ }^{\circ} \mathrm{C}$ for 24 $\mathrm{h}, 120^{\circ} \mathrm{C}$ for $16 \mathrm{~h}$, and $160^{\circ} \mathrm{C}$ for $18 \mathrm{~h}$. The SPI membrane was deprotonated by immersing the membrane in a $1.0 \mathrm{M}$
$\mathrm{HCl}$ solution at room temperature for $48 \mathrm{~h}$. The resulting membrane was thoroughly washed with de-ionized water until neutral and then dried in the vacuum oven at $80^{\circ} \mathrm{C}$ for $24 \mathrm{~h}$.

\subsection{FTIR and ${ }^{1} H$ NMR Spectroscopy}

Fourier transform Infrared (FTIR) spectra of DDM, S-DDM and BTDA were recorded on a Thermo-Nicolet NEXUS 670 FTIR spectrometer using a $\mathrm{KBr}$ pellet as the background material. The FTIR spectra were measured in the wavenumber range of $400 \mathrm{~cm}^{-1}$ to $4000 \mathrm{~cm}^{-1}$. ATR-FTIR technique was used to record the spectrum of SPI with $\mathrm{ZnSe}$ used as a background material.

${ }^{1} \mathrm{H}-\mathrm{NMR}$ spectra were recorded on a Varian Mercury $400 \mathrm{MHz}$ spectrometer. Deuterated dimethylsulfoxide (DMSO- $d_{6}$ ) was used as a solvent.

\subsection{Thermogravimetric Analysis}

Thermogravimatric analysis (TGA) was performed to investigate the thermal stability of the polymer membranes with a Perkins Elmer Pytis Diamond TG/DTA instrument. The samples were heated at a heating rate of $20{ }^{\circ} \mathrm{C} / \mathrm{min}$ under nitrogen atmosphere from $50{ }^{\circ} \mathrm{C}$ to $900{ }^{\circ} \mathrm{C}$.

\subsection{Ion Exchange Capacity}

Ion exchange capacities (IECs) of the sulfonated polyimide membranes were determined by the titration $\operatorname{method}^{13}$. The membranes were cut into small pieces and then immersed in $1.0 \mathrm{M} \mathrm{NaCl}$ solution and stirred for 2 days at room temperature. The solution was titrated with a $0.01 \mathrm{M}$ $\mathrm{NaOH}$ solution with phenolphthalein used as an indicator. The IEC values were calculated with the following equation:

$$
\operatorname{IEC}(\mathrm{meq} / \mathrm{g})=\frac{V_{\mathrm{NaOH}}(\mathrm{ml}) \times C_{\mathrm{NaOH}}(\mathrm{M})}{W_{d r y}(\mathrm{mg})}
$$

where $V_{\mathrm{NaOH}}$ is the added volume of sodium hydroxide solution at the equivalent point, $C_{\mathrm{NaOH}}$ is the molar concentration of the sodium hydroxide solution, and $W_{d r y}$ is the dry weight of the sample in $\mathrm{H}^{+}$form (mg).

\subsection{Degree of sulfonation}

The polymer membranes were acidified by a $0.1 \mathrm{M} \mathrm{HCl}$ solution at room temperature for $24 \mathrm{~h}$. The membranes were washed with deionized water and dried at $80{ }^{\circ} \mathrm{C}$ for $24 \mathrm{~h}$, followed by immersion in a $\mathrm{NaCl}$ solution for $24 \mathrm{~h}$. The DS of the solution was determined by the titration method with $0.01 \mathrm{M} \mathrm{NaOH}$ using phenolphthalein as an indicator. The DS of the membrane was calculated with the following equation:

$$
\operatorname{DS}(\%)=\frac{\left(V_{\text {NaOH }}(\mathrm{ml}) \times C_{\text {NaOH }}(\text { Molar })\right) / 1000}{\text { Mole of polymer membrane }} \times 100
$$

where $V_{\mathrm{NaOH}}$ is the volume of $\mathrm{NaOH}$ consumed, and $\mathrm{C}_{\mathrm{NaOH}}$ is the molar concentration of $\mathrm{NaOH}$. 


\subsection{Water uptake}

Water uptake (\%) was determined by immersing the membranes in distilled water at $80^{\circ} \mathrm{C}$ for $5 \mathrm{~h}$. The membranes were taken out, quickly wiped with tissue paper, and weighed on a microbalance. The percentage of water uptake was calculated by the following equation ${ }^{28}$ :

$$
\text { Water uptake }(\%)=\frac{W_{s}-W_{d}}{W_{d}} \times 100 \%
$$

where $W_{s}$ and $W_{d}$ are the weights of the wet and dry membrane samples, respectively.

\subsection{Proton conductivity}

Proton conductivities $(\sigma)$ of the membranes were determined by an electrochemical impedance spectroscopy (EIS) technique using an Agilent E4980A Precision LCR Meter $^{8}$. The 16451B dielectric test fixture with the type C electrode was used. The sulfonated films were cut into 0.5 $\mathrm{cm} \times 0.5 \mathrm{~cm}$ pieces and submerged in water for $24 \mathrm{~h}$, then the excess water was wiped off, coated with a silver paint before measurement. This measurement condition is referred to as a wet state. The measurement was then carried out at room temperature at $50 \% \mathrm{RH}$. The coated membrane was measured at a $1 \mathrm{~V}$ potential using an alternating current in the frequency range of $20 \mathrm{~Hz}$ to $2 \mathrm{MHz}$. The proton conductivity was calculated by the following equation:

$$
\sigma\left(S . c m^{-1}\right)=\frac{d}{R \times A}
$$

where $\sigma$ is the proton conductivity, $d$ is the thickness of the membrane, $A$ is the area of the interface of the membrane in contact with the electrodes, and $R$ is the resistance which can be derived from the low intersect of the high frequency semicircle on a complex impedance plane with the $\operatorname{Re}(Z)$ or $Z$ ' axis.

\subsection{Methanol permeability}

Methanol permeability $(P)$ was determined by using a liquid permeation cell consisting of two compartments (A and B) separated by a tested membrane ${ }^{11}$. A 2.5 M methanol solution was placed in compartment $A$ and de-ionized water was placed in compartment $\mathrm{B}$. The concentration of the methanol in compartment $\mathrm{B}$ was analyzed using gas chromatography (GC) at $30{ }^{\circ} \mathrm{C}$ and $60{ }^{\circ} \mathrm{C}$. Methanol permeability $(P)$ was calculated by the following equation:

$$
P\left(\mathrm{~cm}^{2} / s\right)=\frac{K_{B} V_{B} L}{A\left(C_{A}-C_{B}\right)}
$$

where $C_{A}$ and $C_{B}$ are the initial methanol concentrations in the feed and permeated compartment, respectively, $V_{B}$ is the volume of the permeate solution, $A$ is the effective area of the membrane, $L$ is the thickness of the membrane, and $k_{B}$ is the methanol concentration gradient vs. time (the slope of methanol concentration profile in the compartment B).

\section{Results and Discussion}

\subsection{Monomer synthesis}

DDM was converted into S-DDM via the direct sulfonation using fuming sulfuric acid as a sufonating agent, as shown in Scheme 1. In the first step, concentrated sulfuric acid (98\%) reacted with the amino group of the DDM to create the quaternary ammonium salt of sulfuric acid. In the second step, $\mathrm{SO}_{3}$ in the fuming sulfuric acid reacted with the DDM to produce the S-DDM. The S-DDM monomer was characterized by ${ }^{1} \mathrm{H}-\mathrm{NMR}$ spectroscopy. Signals assigned to the three aromatic protons of S-DDM appear at $\delta=7.16,7.12$, and 6.71 as shown in figure 1 . The attachment of sulfonic group onto the polyimide chain at the aromatic ring can be referred to the work of Deligoz et al., (2008), the primary amine resonance is apparent as a broad singlet at $\delta=5.55$, whereas the methylene protons resonate at $\delta=3.82^{13}$.
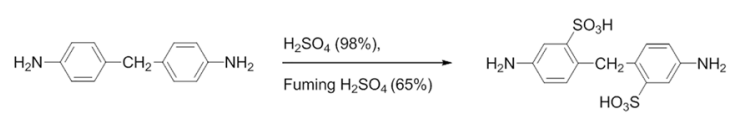

Scheme 1. Synthesis of S-DDM.

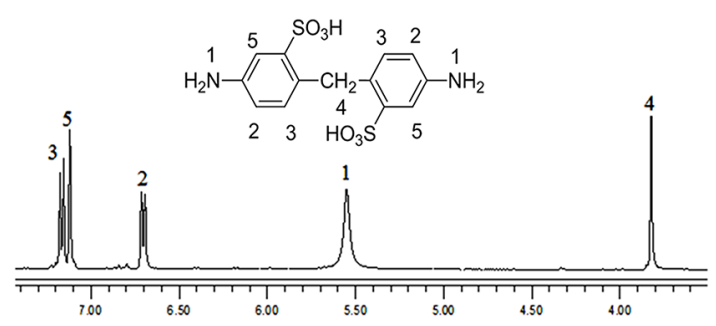

Figure 1. The ${ }^{1} \mathrm{H}-\mathrm{NMR}$ spectrum of S-DDM in DMSO- $d_{6}$.

\subsection{Copolymer synthesis}

The new SPI was successfully synthesized by copolymerization of SDDM, DDM and HDA, as shown in Scheme 2. The molar ratio of SDDM: DDM: HDA was fixed at 1:4:5. The chemical structure of the resulting sulfonated copolyimide was confirmed by FTIR measurements. The unsulfonated copolyimide was also synthesized with the molar ratio of DDM: HDA $=5: 5$. Figure 2 shows that the FTIR spectra of both copolyimides possess the characteristic absorption bands of the imide groups at $1777 \mathrm{~cm}^{-1}$ and 1709 $\mathrm{cm}^{-1}$, which can be attributed to the $\mathrm{C}=\mathrm{O}$ asymmetric and $\mathrm{C}=\mathrm{O}$ symmetric stretchings, respectively ${ }^{24,26,28}$. The band at 1662 $\mathrm{cm}^{-1}$ corresponds to the carbonyl group of benzophenon ${ }^{26}$. The absorption band at $1368 \mathrm{~cm}^{-1}$ is attributed to the characteristic $\mathrm{C}-\mathrm{N}$ stretching of the imide group ${ }^{24,26,28}$. The observation of all characteristic imide bands in both copolyimides indicates complete thermal imidization. In the case of the sulfonated copolyimides, the absorption bands of sulfonic acid groups namely the symmetric and asymmetric S-O stretchings appear 


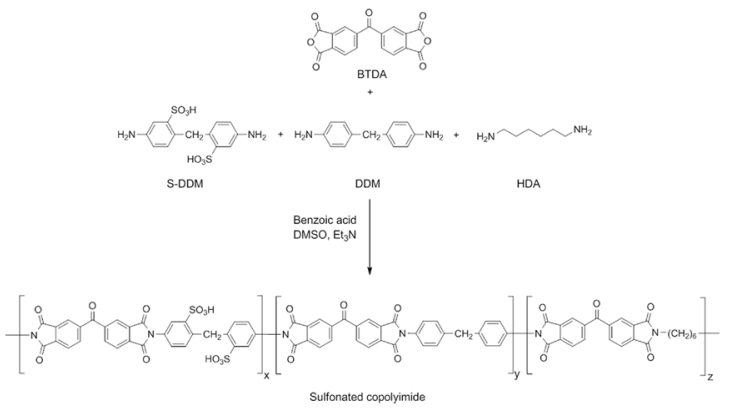

Scheme 2. Synthesis of poly(aromatic imide-co-aliphatic imide) (SPI).

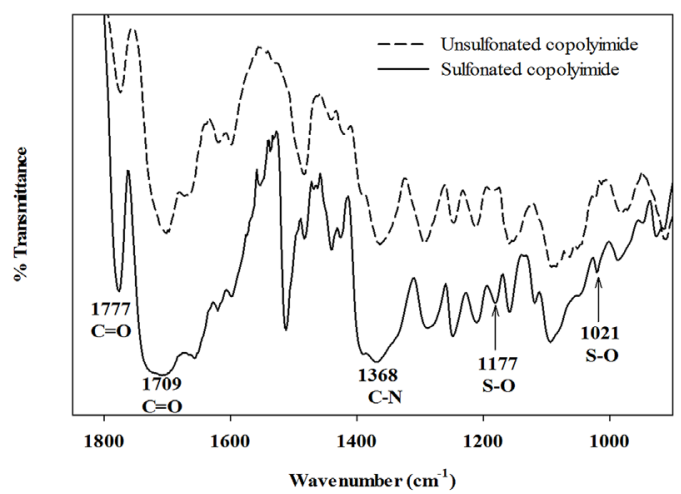

Figure 2. FTIR spectra of unsulfonated and sulfonated copolyimides.

at $1182 \mathrm{~cm}^{-1}$ and $1019 \mathrm{~cm}^{-1}$, respectively ${ }^{24}$. The FTIR band at $1050-1100 \mathrm{~cm}^{-1}$ is due to the stretching of sulfoxide group $(\mathrm{S}=\mathrm{O})$. The sulfonated copolyimide shows a higher peak area and intensity relative to the unsulfonated copolyimide due to the amount of the $\mathrm{S}=\mathrm{O}$ group present ${ }^{23}$.

\subsection{Thermal Stability}

The thermal stability of the membrane is important in DMFC operation. The membrane should be stable when the fuel cells are operated at an elevated temperature in the range of $70-100{ }^{\circ} \mathrm{C}$. Thermogravimetric analyses for sulfonated copolyimide membranes with different molar ratios of S-DDM: DDM: HDA (SDH 0, SDH 1, SDH 2, SDH 3, SDH 4, and SDH 5) were investigated, as tabulated in Table 1. Figure 3 shows that the unsulfonated copolyimide membrane (SDH 0) exhibites only one main weight loss at temperature about $450{ }^{\circ} \mathrm{C}$, corresponding to the degradation of the polymer main chain ${ }^{10,12,13,18}$. All other sulfonated copolyimide membranes (SDH 1-SDH 5) demonstrate a typical two steps degradation pattern. The first weight loss at $200-300{ }^{\circ} \mathrm{C}$ can be ascribed to the decomposition of sulfonic acid groups by desulfonation ${ }^{10,12,13,18}$. This weight loss at $200{ }^{\circ} \mathrm{C}$ is due to the phosphoric acid degradation ${ }^{31}$. It is apparent that weight loss (\%) increases in proportion to the molar concentration of S-DDM or the degree of sulfonation. The second weight loss at $\sim 450{ }^{\circ} \mathrm{C}$ is attributed to the decomposition of the polymer main chain ${ }^{10,12,13,18}$. Thus, all synthesized sulfonated copolyimides show high thermal stability.

\subsection{Degree of sulfonation, ion exchange capacity, and water uptake}

The measured DS values are tabulated Table 1; the maximum DS value is as high as $96 \%$ for the SDH 5 membrane.

IEC is the number of milli-eqivalents of ions in $1 \mathrm{~g}$ of dry membrane. The experimental IEC values of the membranes were determined by the titration method, while the theoretical IEC values were computed by the content of the sulfonic acid groups incorporated into the polymer backbone. In this work, the measurements were carried out for the series of sulfonated copolyimides. The IEC values of copolyimides with the different molar ratios of S-DDM: DDM: HDA are tabulated in Table 1 and the titration method details can be found in Supplementary section, table $\mathrm{S} 1$. The experimental IEC values are $0,0.84$, $1.28,2.20,2.82$, and 3.12 meq.g ${ }^{-1}$; they are slightly lower than the theoretical IEC values which are $0,0.87,1.49$, $2.23,2.97,3.24$ meq. $\mathrm{g}^{-1}$ for the SDH 0 - SDH 5 membranes, respectively. This might be caused by the incomplete proton exchange ${ }^{12,29}$. On the other hand, the experimental IEC value of the commercial Nafion 117 is much lower; it is only 0.95 . Figure 4 shows the plots of DS and IEC of the copolyimides at different molar ratios of S-DDM: DDM: HDA. It can be seen that the IEC value increases linearly with increasing DS.

Table 1. Ion exchange capacity and water uptake (\%) of the sulfonated copolyimides.

\begin{tabular}{ccccc}
\hline Copolymer & $\begin{array}{c}\text { [SDDM]:[DDM]: } \\
{[\text { HDA }]}\end{array}$ & $\begin{array}{c}\text { Degree of sulfonation } \\
(\%)\end{array}$ & IEC (meq. $\left.\mathrm{g}^{-1}\right)\left(30{ }^{\circ} \mathrm{C}\right)$ & $\begin{array}{c}\text { Water uptake }(\%)(30 \\
\left.{ }^{\circ} \mathrm{C}\right)\end{array}$ \\
\hline SDH 0 & $0: 5: 5$ & 0 & 0 & 2.18 \\
SDH 1 & $1: 4: 5$ & 19.32 & 0.84 & 2.14 \\
SDH 2 & $2: 3: 5$ & 34.46 & 1.28 & 2.18 \\
SDH 3 & $3: 2: 5$ & 58.94 & 2.20 & 3.82 \\
SDH 4 & $4: 1: 5$ & 75.96 & 2.82 & 3.20 \\
SDH 5 & $5: 0: 5$ & 96.29 & 3.12 & 1.99 \\
Nafion 117 & - & - & 0.95 & 39.07 \\
\hline
\end{tabular}




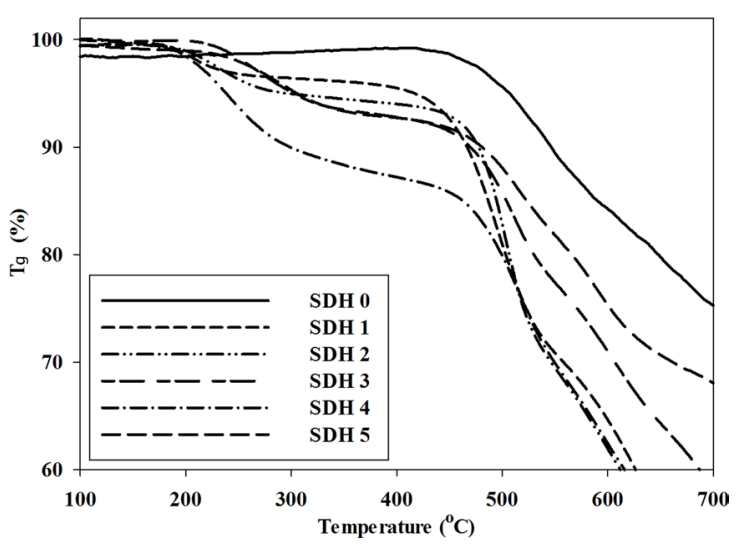

Figure 3. TGA thermograms of the sulfonated copolyimides as SDH 0: [SDDM]: [DDM]:[HDA] = 0:5:5 SDH 1: [SDDM]: $[\mathrm{DDM}]:[\mathrm{HDA}]=1: 4: 5 ;$ SDH 2: [SDDM]: $[\mathrm{DDM}]:[\mathrm{HDA}]=2: 3: 5$; SDH 3: [SDDM]: [DDM]:[HDA] = 3:2:5; SDH 4: [SDDM]: $[\mathrm{DDM}]:[\mathrm{HDA}]=4: 1: 5 ;$ SDH 5: $[\mathrm{SDDM}]:[\mathrm{DDM}]:[\mathrm{HDA}]=5: 0: 5$

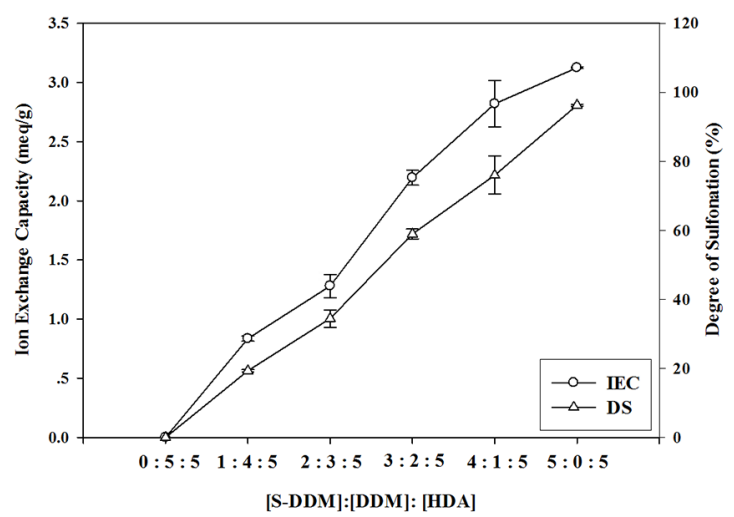

Figure 4. Degree of sulfonation and ion exchange capacity of sulfonated copolyimides.

Water uptake values of the sulfonated copolyimide membranes were measured at $30{ }^{\circ} \mathrm{C}$ and are tabulated in table 1 . The water uptakes of the sulfonated copolyimides are $2.18,2.14,2.18,3.82,3.20$, and $1.99 \%$ corresponding to the SDH 0 - SDH 5, respectively. The water uptake firstly increases with increasing degree of sulfonation due to more available hydrophilic sulfonic groups, then the water uptake decreases for the SDH 4 and SDH 5 (at the 75.96 and 96.29\% degrees of sulfonation) due the higher amount of bulky sulfonic groups present leading to lesser water adsorption capacity. For comparison, the water uptake of the SDH 1 membrane (water uptake $2.14 \%$ ), which has an IEC value (0.84) close to Nafion 117 (0.95), is about ten times lower than that of the Nafion 117 (water uptake 39.07\%) ${ }^{9}$. This can be explained by the rigidity of the polymer chain. The main chain of the SDH 1 consists of the highly rigid aromatic groups whereas the Nafion 117 is composed of much more flexible linear fluorinated aliphatic chains.

\subsection{Proton conductivity and methanol permeability}

Proton conductivity $(\sigma)$ of the SPI membranes was measured after immersing in deionized water for $24 \mathrm{~h}$ at room temperature $\left(30{ }^{\circ} \mathrm{C}\right)$; this condition is referred hereafter as a wet state. The present work was focused at room temperature since the SPI membranes for DMFC are intended to be used in portable electrical devices which are operated at or near room temperature. Proton conductivity monotonically increases with increasing degree of sulfonation as shown in Figure 5. For the sulfonated copolyimides, the proton conductivity values are in the range of 1.603 $\times 10^{-3}$ to $3.241 \times 10^{-3}{\mathrm{~S} . \mathrm{cm}^{-1}}$ at room temperature. The initial increase in the proton conductivity with the degree of sulfonation can be attributed to the available sulfonic groups present. The SDH 5 membrane possesses the highest proton conductivity value of $3.241 \times 10^{-3} \mathrm{~S}_{\mathrm{cm}} \mathrm{cm}^{-1}$. The proton conductivity was calculated from equation 4 , where $R$ was the resistance as obtained from the intersect of the high frequency semi-circle on a complex impedance plane with the $\operatorname{Re}(Z)$ or $Z^{\prime}$ axis of the Nyquist plot as shown in figure

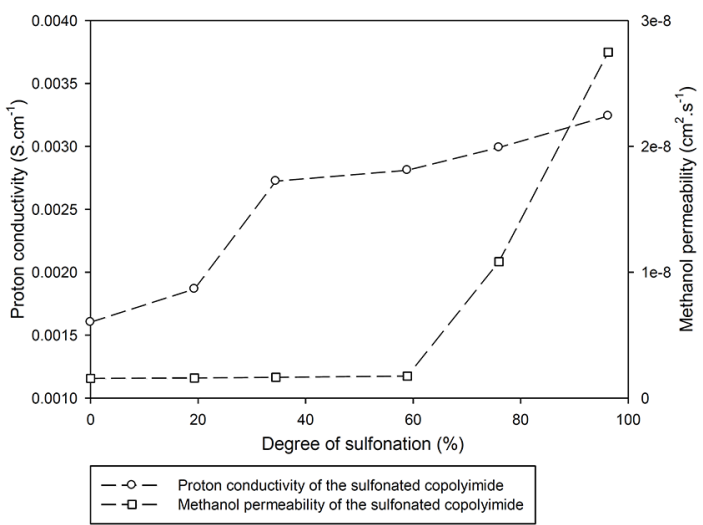

Figure 5. Proton conductivity of sulfonated copolyimides at various DS in the wet state at $30{ }^{\circ} \mathrm{C}$ and methanol permeability of the sulfonated copolyimide membranes measured at $60^{\circ} \mathrm{C}$.

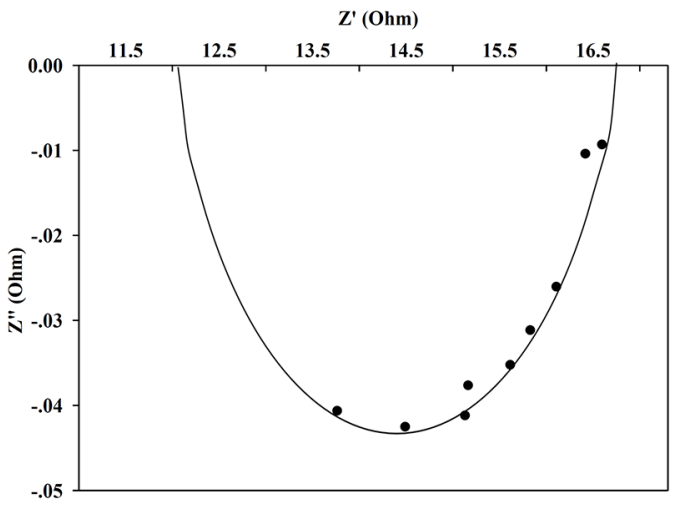

Figure 6. Nyquist plot of SDH 3. 
6 for the SDH 3 membrane. The SDH 5 value is higher than those of the sulfonated polybenzimidazoles produced from 3,3'-disulfonate-4,4'-dicarboxylbiphenyl $\left(2.79 \times 10^{-3}\right.$ S.cm ${ }^{-1}$ at $\left.80{ }^{\circ} \mathrm{C}\right)^{30}$ and the sulfonated polybenzimidazoles produced from 4,8-disulfonly-2,6-naphthalenedicarboxylic acid $\left(2.70 \times 10^{-3} \mathrm{~S}^{-\mathrm{cm}^{-1}} \text { at } 90^{\circ} \mathrm{C}\right)^{30}$. Low proton conductivity of the sulfonated polybenzimidazoles can be attributed to the strong ionic interactions between the basic benzimidazoles and the sulfonic acid groups ${ }^{30}$. The proton conductivity of the sulfonated copolymide SDH 3 is higher than that of the

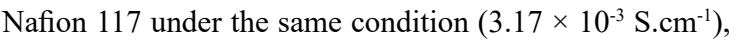
but less than that of the Nafion 117 previously reported $\left(6.83 \times 10^{-3}{\mathrm{~S} . \mathrm{cm}^{-1}}^{17}\right.$. The latter result of the lower proton conductivity may have resulted from the difference in the water uptake of the previously measured Nafion 117. In another related work, the proton conductivity of the sulfonated PBI membrane at $125^{\circ} \mathrm{C}$ showed the highest value of 0.18 ${\mathrm{S} . \mathrm{cm}^{-1}}^{\text {, a higher value than measured at room temperature }}{ }^{31}$.

Methanol permeability $(P)$ is an important parameter for PEMs used in DMFC. To achieve the highest fuel cell performance, PEMS should have low methanol permeability because the methanol crossover from the anode to the cathode causes a lower cell voltage and decreases fuel cell efficiency ${ }^{27}$. Methanol permeability of the sulfonated copolyimide membranes was measured at both $30^{\circ} \mathrm{C}$ and $60{ }^{\circ} \mathrm{C}$ during the measurement period of about one week. The copolymers synthesized had the ability to prevent methanol permeation at $30^{\circ} \mathrm{C}$; the methanol did not sufficiently permeate through the membrane to be measurable within 7 days. At $60^{\circ} \mathrm{C}$, the methanol did not pass through the membranes within the first two days, after that the methanol slightly passed through the membranes and concentration was measurable. Methanol permeability of the sulfonated copolyimide membranes was determined and the results at $60{ }^{\circ} \mathrm{C}$ are displayed in Figure 5. Methanol permeability values of the sulfonated copolyimides fall between $1.56 \times 10^{-9}$ and $2.75 \times 10^{-8} \mathrm{~cm}^{2} \cdot \mathrm{s}^{-1}$. It can be seen that the membrane with a higher sulfonation level possesses higher methanol permeability. Methanol permeation is controlled by the hydrophilic channel size which is composed of the sulfonic acid groups along the copolyimide backbone ${ }^{7}$. Thus, the increase in the sulfonic acid groups result in enlarged interspaces or free volumes between the polymer backbones, through which methanol can pass ${ }^{8}$. The highest measured methanol permeability of the sulfonated copolyimides prepared in this study at $60^{\circ} \mathrm{C}$ is $2.75 \times 10^{-8} \mathrm{~cm}^{2} . \mathrm{s}^{-1}$ which is still $\sim 425$ times lower than that of the commercial Nafion 117 which was measured at same condition $\left(1.17 \times 10^{-5} \mathrm{~cm}^{2} \cdot \mathrm{s}^{-1}\right.$ at $\left.60^{\circ} \mathrm{C}\right)$. The methanol permeabilities of Nafion 117 and Sterion L-180 were 1.2 $\times 10^{-6}$ and $1.4 \times 10^{-6} \mathrm{~cm}^{2} \cdot \mathrm{s}^{-1}$ at $55^{\circ} \mathrm{C}^{3}$. The present SPI membranes possess lower methanol permeability values relative to the the Sterion L-180 by about 50 times. The low methanol permeability of the sulfonated copolyimides may be explained by the physical crosslinking between the polymer chains, the lower water uptake, and the rigidity of the aromatic backbone, preventing methanol crossover. In summary, low methanol permeability data obtained suggest that the synthesized sulfonated copolyimides have a high potential for DMFC applications. The membrane selectivity (s.S.cm ${ }^{-3}$ ) was calculated from the ratio between the proton

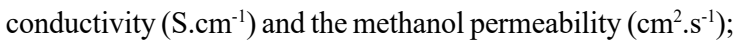
the higher membrane selectivity is preferable for DMFC. The membrane selectivities of the copolyimide membranes are $1.02 \times 10^{6}, 1.17 \times 10^{6}, 1.65 \times 10^{6}, 1.61 \times 10^{6}, 2.76 \times 10^{5}$, and $1.18 \times 10^{5}$ s.S.cm ${ }^{-3}$ belonging to the SDH $0-$ SDH 5 membranes, respectively. On the other hand, the membrane selectivity of the Nafion 117 is relatively low at $1.82 \times$ $10^{3} \mathrm{~s} . \mathrm{S} \mathrm{cm}^{-3}$. The highest membrane selectivity, the ratio between proton conductivity and methanol permeability, is $1.65 \times 10^{6} \mathrm{~s} .{\mathrm{S} . \mathrm{cm}^{-3}}^{-3}$ belonging to the SDH 2 membrane with the $34.46 \%$ degree of sulfonation. The highest membrane selectivity value suggests that the SDH 2 membrane to be the most suitable for the DMFC application.

\section{Conclusions}

Sulfonated copolyimides, of various DS, were successfully synthesized and characterized by FTIR spectroscopy. The synthesized sulfonated copolyimides withstood well at high temperature where the first degradation of the sulfonic group occurred at $200-300{ }^{\circ} \mathrm{C}$. The IEC value increased with increasing sulfonation level. Water uptake of the sulfonated copolyimides was less than $4 \%$. Proton conductivities of the sulfonated copolyimides at room temperature depended on the proportion of S-DDM, and the proton conductivity values were in the range of 1.603 $\times 10^{-3} \mathrm{~S} . c m^{-1}$ to $3.241 \times 10^{-3} \mathrm{~S} . \mathrm{cm}^{-1}$. Methanol permeability of the sulfonated copolyimides also depended on the DS; a higher sulfonation level can be correlated with a higher methanol permeability. The highest measured methanol permeability of the sulfonated copolyimides obtained in this work was $2.75 \times 10^{-8} \mathrm{~cm}^{2} \cdot \mathrm{s}^{-1}$, which is much lower than that of Nafion 117 . The highest membrane selectivity of $1.65 \times 10^{6} \mathrm{~s} .{\mathrm{S} . \mathrm{cm}^{-3}}^{3}$ belonged to the sulfonated copolyimide membrane with the $34.46 \%$ degree of sulfonation (SDH 2) for use in DMFC. Overall, the fabricated SPI membranes possessed higher selectivity values when compared to the commercial Nafion 117.

\section{Acknowledgements}

The authors would like to acknowledge financial supports from the Conductive and Electroactive Polymers Research Unit and the CU-2 ${ }^{\text {nd }}$ Century Grant of Chulalongkorn University, the Thailand Research Fund (TRF), and the Royal Thai Government. 


\section{References}

1. Barbir F, Gómez T. Efficiency and economics of proton exchange membrane (PEM fuel cells. International Journal of Hydrogen Energy. 1996;21(10):891-901.

2. Carrette L, Friedrich KA, Stimming U. Fuel cells - Fundamentals and Applications. Fuel Cells. 2001;1(1):5-39.

3. Lobato J, Cañizares P, Rodrigo MA, Linares JJ, Fernández-Fragua A. Application of Sterion ${ }^{\circledR}$ membrane as a polymer electrolyte for DMFCs. Chemical Engineering Science. 2006;61(14):4773-4782.

4. Lee CH, Park CH, Lee YM. Sulfonated polyimide membranes grafted with sulfoalkylated side chains for proton exchange membrane fuel cell (PEMFC) applications. Journal of Membrane Science. 2008;313(1-2):199-206.

5. Genies C, Mercier R, Sillion N, Cornet GG, Pineri M. Soluble sulfonated naphthalenic polyimides as materials for proton exchange membranes. Polymer. 2001;42(2):359-373.

6. Li Q, Xu Z, Yi C. Preparation of poly(amic acid) and polyimide derived from 3,3', 4,4'-benzophenonetetracarboxylic dianhydride with different diamines by microwave irradiation. Journal of Applied Polymer Science. 2008;107(2):797-802.

7. Park HB, Lee CH, Sohn JY, Lee YM, Freeman BD, Kim HJ. Effect of crosslinked chain length in sulfonated polyimide membranes on water sorption, proton conduction, and methanol permeation properties. Journal of Membrane Science. 2006;285(1-2):432443.

8. Wu D, Fu R, Xu T, Wu L, Yang W. A novel proton-conductive membrane with reduced methanol permeability prepared from bromomethylated poly(2,6-dimethyl-1,4-phenylene oxide) (BPPO). Journal of Membrane Science. 2008;310(1-2):522-530.

9. Woo Y, Oh SY, Kang YS, Jung B. Synthesis and characterization of sulfonated polyimide membranes for direct methanol fuel cell. Journal of Membrane Science. 2003;220(1-2):31-35.

10. Zhai F, Gou X, Fang J, Xu H. Synthesis and properties of novel sulfonated polyimide membranes for direct methanol fuel cell application. Journal of Membrane Science. 2007;96(1-2):102109.

11. Zhu X, Pan H, Liang Y, Jian X. Synthesis and properties of novel sulfonated polyimides containing phthalazinone moieties for PEMFC. European Polymer Journal. 2008;44(11):3782-3789.

12. Deligöz H, Vantansever S, Koç SN, Öksüzömer F, Özgümüs S, Gürkaynak MA. Preparation of sulfonated copolyimides containing aliphatic linkages as proton-exchange membranes for fuel cell applications. Journal of Applied Polymer Science. 2008;110(2):1216-1224.

13. Xu H, Chen K, Guo X, Fang J, Yin J. Synthesis of novel sulfonated polybenzimidazole and preparation of cross-linked membranes for fuel cell application. Polymer. 2007;48(19):5556-5564.

14. Han SI, Im SS, Kim DK. Dynamic mechanical and melt rheological properties of sulfonated poly(butylene succinate) ionomers. Polymer. 2003;44(23):7165-7173.

15. Okamoto K, Yin Y, Yamada O, Islam MN, Honda T, Mishima $\mathrm{T}$, et al. Methanol permeability and proton conductivity of sulfonated co-polyimide membranes. Journal of Membrane Science. 2005;258(1-2):115-122.
16. Matasuguchi M, Takahashi H. Methanol permeability and proton conductivity of a semi interpenetrating polymer networks (IPNs) membrane composed of Nafion ${ }^{\circledR}$ and cross-linked DVB. Journal of Membrane Science. 2006;281(1-2):707-715.

17. Li N, Cui Z, Zhang S, Wei X. Synthesis and characterization of rigid-rod sulfonated polyimides bearing sulfobenzoyl side groups as proton exchange membranes. Journal of Membrane Science. 2007;295(1-2):148-158.

18. Blázquez JA, Iruin JJ, Eceolaza S, Marestin C, Mercier R, Mecerreyes D, et al. Solvent and acidification method effects in the performance of new sulfonated copolyimides membranes in PEM-fuel cells. Journal of Power Sources. 2005;151:63-68.

19. Fang J, Guo X, Harada S, Watari T, Tanaka K, Kita H, et al. Novel Sulfonated Polyimides as Polyelectrolytes for Fuel Cell Application. 1. Synthesis, Proton Conductivity, and Water Stability of Polyimides from 4,4(-Diaminodiphenyl Ether-2,2(disulfonic Acid. Macromolecules. 2002;35(24):9022-9028.

20. Vallejo E, Pourcelly G, Gavach C, Mercier R, Pineri M. Sulfonated polyimides as proton conductor exchange membranes. Physicochemical properties and separation $\mathrm{H}^{+}$ $\mathrm{M}^{2+}$ by electrodialysis comparison with a perfluorosulfonic membrane. Journal of Membrane Science. 1999;160(1):127137.

21. Wang Z, Li X, Zhao X, Ni H, Na H. Synthesis and characterization of sulfonated poly(arylene ether ketone ketone sulfone) membranes for application in proton exchange membrane fuel cells. Journal of Power Sources. 2006;160(2):969-976.

22. Ye X, Bai H, Ho WSW. Synthesis and characterization of new sulfonated polyimides as proton-exchange membranes for fuel cells. Journal of Membrane Science. 2006;279(1-2):570-577.

23. Deligöz H, Yilmazoglu M. Development of a new highly conductive and thermomechanically stable complex membrane based on sulfonated polyimide/ionic liquid for high temperature anhydrous fuel cells. Journal of Power Sources. 2011;196(7):3496-3502.

24. Yin Y, Fang J, Cui Y, Tanaka K, Kita H, Okamoto K. Synthesis, proton conductivity and methanol permeability of a novel sulfonated polyimide from 3-(2(,4(- diaminophenoxy)propane sulfonic acid. Polymer. 2003;44(16):4509-4518.

25. García MG, Marchese J, Ochoa NA. Aliphatice-aromatic polyimide blends for $\mathrm{H} 2$ Separation. International Journal of Hydrogen Energy. 2010;35(17):8983-8992.

26. Huang YJ, Ye YS, Yen YC, Tsai LD, Hwang BJ, Chang FC. Synthesis and characterization of new sulfonated polytriazole proton exchange membrane by click reaction for direct methanol fuel cells (DMFCs). International Journal of Hydrogen Energy. 2001;36(23):15333-15343.

27. Lee CH, Wang YZ. Synthesis and characterization of epoxybased semi-interpenetrating polymer networks sulfonated polyimides proton-exchange membranes for direct methanol fuel cell applications. Journal of Polymer Science Part A: Polymer Chemistry. 2008;46(6):2262-2276.

28. Pan H, Zhu X, Jian X. Synthesis and properties of sulfonated copoly(phthalazinone ether imides) as electrolyte membranes in fuel cells. Electrochimica Acta. 2010;55(3):709-714. 
29. Kang S, Zhang C, Xiao G, Yan D, Sun G. Synthesis and properties of soluble sulfonated polybenzimidazoles from 3,3(-disulfonate4,4(-dicarboxylbiphenyl as proton exchange membranes. Journal of Membrane Science. 2009;334(1-2):91-100.

30. Qing S, Huang W, Yan D. Synthesis and properties of soluble sulfonated polybenzimidazoles. Reactive and Functional Polymers. 2006;66(2):219-227.
31. Lobato J, Cañizares P, Rodrigo MA, Úbeda D, Javier Pinar F. A novel titanium PBI-based composite membrane for high temperature PEMFCs. Journal of Membrane Science. 2011;369(1-2):105-111.Supplementary material

The following online material is available for this article: Table S1. Ion Exchange Capacity (IEC)

Figure S1. Dynamic mechanical analysis (DMA) 